This item was submitted to Loughborough's Research Repository by the author.

Items in Figshare are protected by copyright, with all rights reserved, unless otherwise indicated.

\title{
Community-partnered contracts in developing countries
}

PLEASE CITE THE PUBLISHED VERSION

PUBLISHER

(C) Thomas Telford Publishing

LICENCE

CC BY-NC-ND 4.0

\section{REPOSITORY RECORD}

Sohail, M., and Andrew N. Baldwin. 2019. "Community-partnered Contracts in Developing Countries". figshare. https://hdl.handle.net/2134/3880. 
This item was submitted to Loughborough's Institutional Repository (https://dspace.lboro.ac.uk/) by the author and is made available under the following Creative Commons Licence conditions.

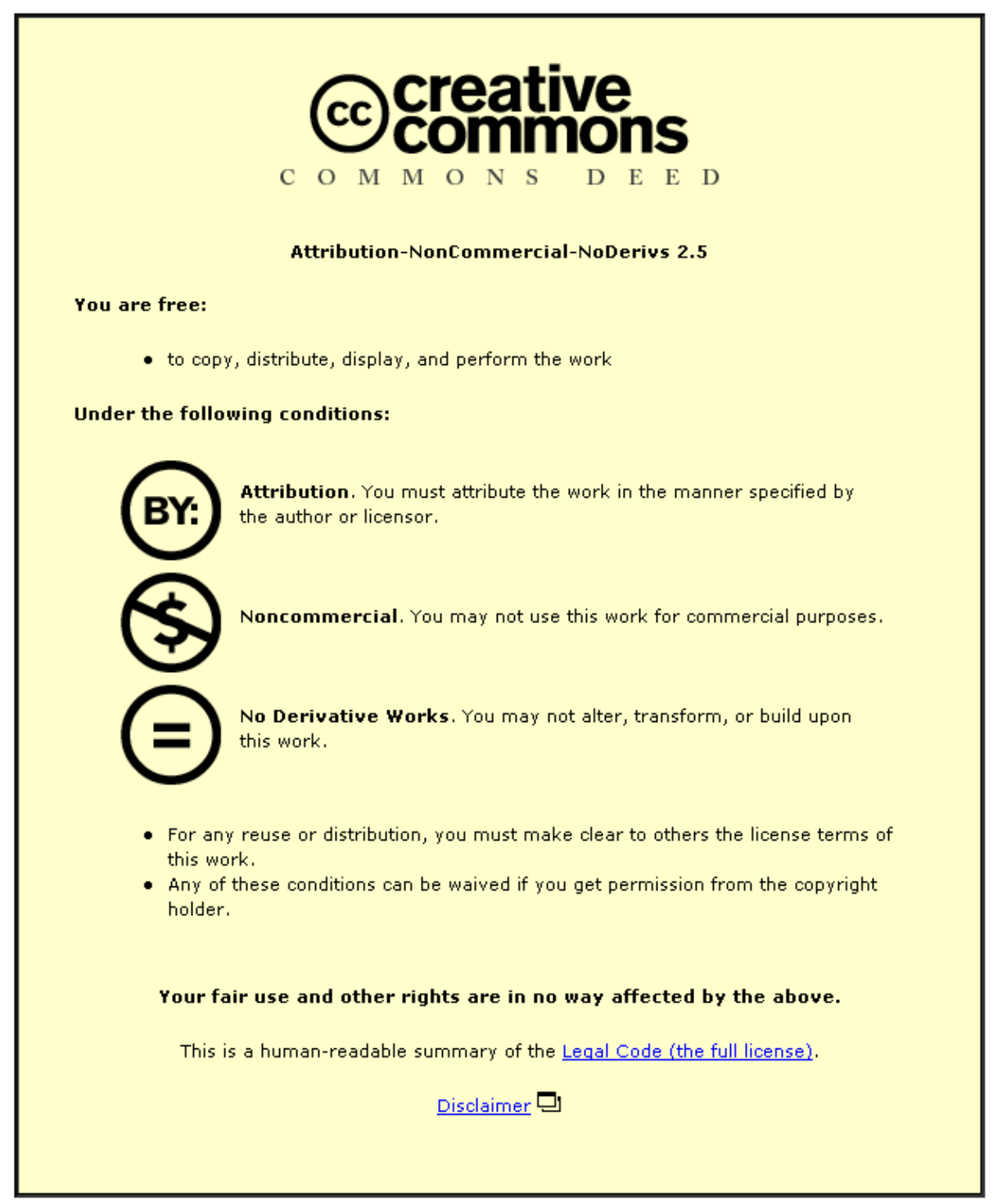

For the full text of this licence, please go to: http://creativecommons.org/licenses/by-nc-nd/2.5/ 


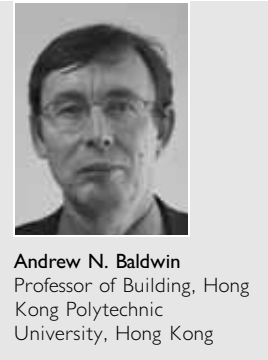

\title{
Community-partnered contracts in developing countries
}

\author{
M. Sohail PhD, MASCE and A. N. Baldwin MSc, CEng, FICE
}

There is a growing recognition in developing countries of community-based infrastructure procurement and its potential to achieve sustainable development. The advantages of such an approach are that it encourages participative negotiation of activities and speedier implementation, the use of local resources, skills and appropriate technology, and entrepreneurship within communities. These wider socio-economic impacts arising from community-partnered micro-projects can lead to more sustainable infrastructure through meeting local stakeholders' needs, community empowerment and capacity building. This paper describes the development and use of performance indicators for community-contracted urban infrastructure provision in low-income communities in India, Pakistan and Sri Lanka. In particular, these indicators refer to the dimensions of time and cost; some key performance yardsticks are also proposed. The urban infrastructure and services referred to in these cases are the facilities needed for water and sanitation provision, access roads, street lighting and solid waste management. In general, it was found that costs for community-contracted micro-projects were normally very close to being on target. The quality of infrastructure and service provision also tended to be superior to that envisioned by local government engineers. However, project duration generally exceeded the target but was still comparable to conventional contracts. The overall performance of the community-partnered micro-projects was found to be comparable or better than the conventional micro-contracts; in addition, the performance of these projects in terms of socio-economic elements was likely to far exceed that of the conventional micro-projects.

\section{INTRODUCTION}

By 2020, more than half of the world's population will be living in urban areas. ${ }^{1}$ In many cities, between 40 and 50\% of the population already live in slum or squatter settlements, which lack basic services. ${ }^{2,3}$ The provision of urban services to city dwellers, in both formal and informal settlements, is therefore one of the biggest challenges faced by urban services managers in developing countries.

The public sector has failed to meet such challenges, one of the main reasons for this being widespread inertia which hampers its ability to respond to fast-changing circumstances. There is thus an urgent need for innovation in the delivery of sustainable urban services. Sustainability is an increasingly used term and has a number of meanings depending upon the context. For the purposes of this study, urban services can be said to be sustainable if the benefits of the service are realised over a sustained period of time.

The concept of sustainable development in the context of urban infrastructure becomes pertinent in the context of imbalances of supply and demand. Parkin ${ }^{4,5}$ discussed the issues relating to sustainable development and came up with the notion of 'capacity for continuance'. The implication of the concept to the current research is that urban infrastructure-along with its wider impacts on social development-is a key contributor to 'capacity for continuance'.

While international development practitioners have experimented with urban service delivery to ensure 'capacity for continuance', primarily through pilot projects, very few of these have been scaled up and mainstreamed. There is also a lack of data on the policy impacts of those 'successful' pilots.

This paper is about one type of innovation - that is, community-partnered procurement-and it provides evidence that community contracts still exist after a decade, are working, and that they are being mainstreamed and have potential for further use. The paper is based on a long-term (six-year) research programme on community contracts and performance monitoring of micro-projects conducted by the Water, Engineering and Development Centre (WEDC), Loughborough University, UK.

Provision of urban services includes procuring infrastructure projects that vary in size from large- to small-scale works. Procurement is the process of buying goods, works and services. There is no consensus on what exactly constitutes 'small'. For example, the World Bank ${ }^{6}$ refers to 'small-scale' projects as those projects that have a total cost less than US $\$ 10$ million. However, in the context of many South Asian countries - in fact, in most of the developing world-many small-scale projects have a total cost of a less than US $\$ 15000$. Development economists and engineers term these 'microprojects'. They are the focus of this research, because the majority of public works projects undertaken in developing countries are of this size. The nature of these projects includes the procurement of water and sanitation, constructing access 
roads/pavements, solid waste-related construction and providing small community buildings at a neighbourhood level.

Unfortunately there is a general lack of performance-related information on such infrastructure, particularly that provided through community-partnered contracts. This in turn is the reason why such contracts are not being considered for wider and more frequent use in developing countries. This general lack of data is felt most acutely with respect to micro-projects. At the outset of this research there was no international performance analysis available, using yardsticks or indicators, for monitoring the procurement and completion of such projects. The principal challenge of this research was to address this issue.

This research is based on data from a total of 800 'microcontracts'; of these, 400 were community-partnered contracts, awarded by urban local authorities and non-governmental organisations (NGOs) in South Asia-specifically, India, Pakistan and Sri Lanka. This paper provides a brief overview of the procurement process used in these three countries, all of which have a common legal framework developed during colonial times under British law.

The paper is primarily concerned with time and cost issues in community-partnered contracts in developing countries and describes the development and use of a range of performance indicators on these issues that may be used for micro-projects. These indicators cover the procurement, execution and completion of works. Inter-organisational cooperation and partnership indicators, together with indicators of the quality of work and social benefits, are discussed more fully elsewhere. ${ }^{7}$

In order to understand the context of the research, the following sections briefly describe the key roles in the procurement process, an outline of a typical public works procurement process, and the concept of community-partnered procurement.

\section{AN OUTLINE OF A TYPICAL PROCUREMENT PROCESS}

The three roles in the procurement process are the promoter, the engineer and the contractor. The promoter plans and prepares briefs, commissions design work and hires an engineer. He or she in turn is usually responsible for design, monitoring and quality assurance of the contracts and for hiring a contractor to undertake the construction work.

In many government organisations, the engineer is a full-time employee. It is rare for private-sector consultants to fulfil this role for minor engineering works. The promoter wants the best value for money and the contractor wants to maximise profit. While this relationship can involve complex and contentious issues, satisfactory performance can be broadly defined in terms of the following three fundamental objectives.

(a) Quality: has the work been done in accordance with what was specified?

(b) Time: has the work been completed satisfactorily within the time specified?

(c) Cost: has the work been completed within the costs agreed in the contract?
Procurement of urban infrastructure in the public sector is regulated by the relevant legal, financial, municipal and administrative rules. These rules were typically set out in Public Works Department (PWD) procedures of the local governments in the study countries.

The key steps that must be taken from when the need for infrastructure is established to completion of the contract are outlined in Table 1.

The costs associated with the project are as follows.

(a) 'Technical sanction cost' is the cost on which the approval of the project is based.

(b) 'Engineer's estimate' is the cost on which the tenders are called and later evaluated.

(c) 'Tender/contract letting cost' is the cost on which the contract is awarded.

(d) 'Completion cost' is the final cost of the contract, including variations.

The chain of responsibility involves action by many different officials. The whole process of procurement is very sensitive to delays in approval procedures, which in turn cause delays in awarding the contract and later delays in infrastructure delivery. Furthermore, the accuracy of the estimates upon which the contract cost is evaluated is critical, as departmental budgetary ceilings restrict payments to contractors.

\section{COMMUNITY-PARTNERED PROCUREMENT}

A community contract is a contract between a community and another partner (which could be for example the public sector, the private sector, or a donor organisation) to undertake tasks to improve or contribute to improving the living conditions of the community. Since community contracting is relatively new, the standard for community contracts is non-existent. The conventional conditions of a contract are designed to use professional contractors and as such are restrictive in terms of community involvement. Community contracting can also be defined as "the contracting out of the construction component of infrastructure procurement to a community'. An early description of community construction contracts in the context of Sri Lanka is provided by Pathirana and Sheng. ${ }^{8}$

Over the past few decades, technology and resource-based development theories that concentrate on technology transfer have been replaced by theories advocating the use of appropriate technology with community participation. These new paradigms take a more people-orientated approach and involve the intended beneficiaries in the planning and implementation of projects. This approach is particularly apparent in microprojects, since conventional contracts, regulatory instruments and legal frameworks typically lack explicit requirements for contractors to involve communities in the installation, operation and maintenance of infrastructure or in the monitoring of the quality of service received. For example the contract typically does not define the roles and responsibilities of the operator and of any community-based organisation involved with the installation or maintenance of infrastructure or in secondary distribution. Additionally, the contract may not include a recommendation that communities be consulted in the preparation of detailed service plans or make specifications for a range of service delivery modes to be used to suit different 


\begin{tabular}{|c|c|}
\hline Narrative & Commentary \\
\hline $\begin{array}{l}\text { 1. Formulation of a scheme } \\
\text { and its requirements }\end{array}$ & $\begin{array}{l}\text { Need not necessarily be done by the engineering department (ED); the ED procurement } \\
\text { procedure starts once the requirements of the scheme have been put before it, regardless of } \\
\text { their origin. }\end{array}$ \\
\hline $\begin{array}{l}\text { 2. Preliminary cost estimates } \\
\text { are prepared }\end{array}$ & In general, the basis is 'rule of thumb' and use of past data. \\
\hline $\begin{array}{l}\text { 3. Administrative approval of } \\
\text { estimates }\end{array}$ & $\begin{array}{l}\text { Approval by the designated officials authorises the initiation of the work. The larger the scale of } \\
\text { the works, the more senior is the approving official. Some officials, such as the chief engineer, } \\
\text { have unlimited powers. }\end{array}$ \\
\hline $\begin{array}{l}\text { 4. Preparation of surveys, } \\
\text { designs and detailed cost } \\
\text { estimates }\end{array}$ & $\begin{array}{l}\text { The basis of these cost estimates is the government-approved Schedule of Rates and approved } \\
\text { details. The Public Works Department (PWD) is the main source of reference in this regard. }\end{array}$ \\
\hline $\begin{array}{l}\text { 5. Approvals by appropriate } \\
\text { officials in the ED; this } \\
\text { usually involves the chief } \\
\text { engineer and is termed } \\
\text { 'technical sanction' }\end{array}$ & $\begin{array}{l}\text { Technical and financial feasibility authorisation. The official giving such approvals must be sure } \\
\text { that the proposed work is technically feasible and financially viable. The designs and estimates } \\
\text { are scrutinised in detail. The procedure prescribes the level of the official who is to give } \\
\text { approval depending on the scale of the works. }\end{array}$ \\
\hline 6. Notice inviting tender & $\begin{array}{l}\text { A notice to the potential contractors to submit tenders for the notified work. The procedure } \\
\text { prescribes the level at which the notice should be advertised: in the case of some very small- } \\
\text { scale works, pasting a notice on a board in the offices is sufficient; in the case of larger } \\
\text { contracts, the notice should be advertised in the national or international newspapers for a } \\
\text { minimum number of days. }\end{array}$ \\
\hline 7. Tender opening & $\begin{array}{l}\text { Offers are opened in the presence of a committee. The committee comprises a technical } \\
\text { section, legal branch and accounts department. The offers are read aloud in the presence of the } \\
\text { tenderers and recorded in a register. The committee then signs the register. The idea is to } \\
\text { ensure that no changes are made in the bid price after the bid opening. }\end{array}$ \\
\hline 8. Work order start date & $\begin{array}{l}\text { This signifies that start of the contract. This is a letter issued by the authorised official advising } \\
\text { the contractor to start the work within a certain number of days. The contract duration starts } \\
\text { from the date of issue of this letter. }\end{array}$ \\
\hline 9. Actual start date & $\begin{array}{l}\text { The date work starts on site may differ from the authorised date. Although in micro-contracts } \\
\text { there is no prescribed mobilisation advance, many work orders demand that the work be } \\
\text { started within seven working days from the date of issue of the work order. }\end{array}$ \\
\hline 10. Completion of the work & $\begin{array}{l}\text { This is marked by the date of the last measurement done at site. In many cases a 'measurement } \\
\text { book' is used and the designated official takes the measurements and enters them in the } \\
\text { presence of the contractor. In public-sector procurement governed by the PWD rules, the } \\
\text { entry in the measurement book is the final recording and cannot be challenged. }\end{array}$ \\
\hline $\begin{array}{l}\text { 11. Facility becomes } \\
\text { operational }\end{array}$ & $\begin{array}{l}\text { In some cases, the infrastructure does not come into use at the same time as the work contract } \\
\text { is completed. There are some time lags involved, for example between the time when water } \\
\text { supply pipelines are completed and when the water is actually supplied through those lines. For } \\
\text { the end user, the operational date of the infrastructure is important rather than just the date } \\
\text { when the contract is completed. }\end{array}$ \\
\hline $\begin{array}{l}\text { 12. End of the defects liability } \\
\text { period }\end{array}$ & $\begin{array}{l}\text { Marked by the last entry of the measurement book, as reflected in the completion certificate. } \\
\text { Usually six months after completion of the work. }\end{array}$ \\
\hline
\end{tabular}

circumstances. Furthermore, clear definitions of service delivery are often not provided for 'poor' communities or those without legal land title.

In general, the traditional bid evaluation process is based on a system in which technical proposals are evaluated on the basis of the lowest cost. The operator's previous track record of involving communities in service delivery often does not count towards its chances of selection, thus there is little incentive for large-scale operators, delivering conventional technical solutions, to involve local communities in service delivery.

Professionals involved in infrastructure provision have traditionally been interested in the efficiency with which faculties have been provided, the costs of works, the time taken to complete them and their quality. Community involvement in infrastructure procurement is aimed to address these traditional concerns but also ensures that service provision is more relevant to local needs, the physical and financial conditions and the social and institutional circumstances. Such an approach would ensure that services could be operated and maintained in a sustainable fashion such that they improve people's environments and life chances. Community contracting may also result in empowerment-related goals in terms of increased access to information, increased ability to negotiate with external stakeholders in urban service provision, and direct and indirect economic benefits from procurement for communities. Further details of community-contracting projects can be found in References 10-12. 


\section{RESEARCH METHODOLOGY}

This research explores approximately 800 micro-contracts awarded by urban local authorities, special projects and NGOs in South Asia. These contracts covered both conventional tender contract and community contracting processes. An analytical framework based on benchmarking and the development of key performance indicators was applied to data relating to micro-projects in the study countries. In this research, benchmarking is understood as 'a position against which performance can be measured' and performance indicators are 'an item of information that is collected to record some aspect of an activity or a system. ${ }^{12}$

During the research programme, 125 detailed, semi-structured interviews were conducted with contract administrators in both the client and contractor organisations. The contract files were also reviewed, including: the necessary approvals; dates when such approvals were obtained; and who took the actual decisions. The contract file is also important as it is used for the audit purposes. The literature review, interview and focus group discussions were used to

(a) analyse the process of procurement in low-income countries

(b) identify the stakeholders involved at each stage, along with the roles and responsibilities of the people involved

(c) identify data relevant to each stage and their time and cost dimensions

(d) define the key performance indicators for community contracts

(e) propose benchmarks for contracts.

Focus group discussions with 12 expert contract administrators were used to validate the performance-monitoring indicators and the proposed yardsticks. The indicators were field-tested on a number of micro-contracts related to urban infrastructure.

\section{I. Performance monitoring indicators}

The past decade has seen considerable research into the development and implementation of performance indicators for many different types of construction work. A performance indicator can be defined as 'an item of information collected at regular intervals to track the performance of a system'. For example, the emphasis on total quality management has led to benchmarking ${ }^{13}$ and this in turn has impacted on the development of key performance indicators (KPIs). In the UK, these initiatives were to a significant extent a direct response to both the Latham ${ }^{14}$ and Egan reports. ${ }^{15}$ In 1999, the UK Department of Trade and Industry launched its first set of KPIs and these in turn have been developed for different sectors of the construction industry - for example, New Build Social Housing, New Build Private Housing, Major Infrastructure Projects and so on. ${ }^{16}$

These KPIs were then followed by indicators for different disciplines - for example, for consultants, and for mechanical and electrical contractors-and in 2001, by indicators aimed specifically at design. Further details of these KPIs can be found on the Construction Best Practice Programme website. ${ }^{17}$

Performance indicators have also been used in developing countries to identify key areas for improvements and as a useful tool for shaping further urban service delivery programmes and policies, particularly in terms of 'micro-projects'. Performance indicators for community micro-projects include the dimensions of time, cost and quality, inter-organisation, cooperation and partnership as well as socio-economic issues. These indicators have been used as a valuable management tool for monitoring and evaluating community contracting, by highlighting successes and failures in the procurement process.

A wide variety of indicators were developed during this study. More detailed discussion on the development of the performance indicators can be found in Reference 7. The following indicators are of most relevance in the context of the present paper (see Table 3 for a more detailed description). These performance indicators can be broken down into quantitative and qualitative types.

The quantitative performance indicators developed include the following.

- R1 Cost growth = final contract cost/initial contract cost.

- R2 Time growth = final contract duration/initial contract duration.

- R3 Lead time = time required to commence works/contract duration.

- R4 Accuracy of preliminary technical estimates.

- R5 Proximity of engineers' estimated cost and the initial contract cost.

- R6 Proximity of engineers' estimated cost and the final contract cost.

- TL1 Time taken from approval stage to reach the tender inviting stage or equivalent stage.

- TL9 Time taken between tender invitation and the start of contract.

- TL13 Time taken to start operation and maintenance after the contract is completed.

The use of ratios made it possible to compare the cost-related data without normalisation, as the comparison is not between the costs themselves but between the ratios. All the subsequent benchmarks are defined as ratios.

The opinions of service users are also a critical component of assessments of the quality of construction work. Qualitative performance indicators for community contracting refer to quality, inter-organisational cooperation and partnership and socio-economic issues. These were investigated as part of an indepth participatory assessment.

(a) Quality: whether the contractor meets the required standards to measure quality performance.

(b) Inter-organisational cooperation and partnership: the ways in which officials and the community interact, and the degree of cooperation between them, can significantly affect the efficiency and success of the project.

(c) Socio-economic issues: in addition to the infrastructure itself a community may receive a number of other benefits as a result of infrastructure procurement. These may be skill development through training, increased employment and feelings of empowerment.

The focus of this paper is on the analysis of some performance 
indicators relating to community contracting. The use of the indicators is, in most cases, straightforward, with the need to collate information on events, monitor trends, and track changes in responsibility and control.

\subsection{Data analysis}

SPSS for Windows was used for statistical analysis in this report. Table 2 presents the selected descriptive statistics for the group of micro-projects studied. Table 3 provides the calculated performance indicators. However, the information required to calculate all the ratios for all the groups was not available.

The 95\% confidence intervals and standard deviations were also calculated. A measure of central tendency was chosen after examining the consistency of the measures. In general, the mean gives a consistent measure of the central tendency of the data. Considering low effects on the overall outcome, consistency across contracts of the different organisations, and taking into consideration previous studies, ${ }^{18}$ the mean was taken as the most appropriate indicator. The results were as outlined below.

Analysis of the performance data shows that, when reviewing the indicator — for example, R1 (cost growth)—obtained for the community-partnered contracts awarded by SKAA (Sindh Katchi Abadi Authority) the final contract cost was, on average, only 0.67 times the initial cost (equivalent to a cost saving of $33 \%$ against the estimate). Hence it was found that the project costs had been consistently overestimated. From the data available and the supporting documentation it was not clear why this was the case. (In such instances, further investigation is needed with the respective managers.) This represents one area where improvements could be made.

It should not of course be automatically assumed that this level of performance is beneficial. While it represents a saving, there is a downside - that is, original budgets may not be spent fully and construction may be delayed as a result. This is evident when factor R2 (time growth) is examined for the same SKAA contracts. Analysis of indicator R2 shows that the average time growth on the same projects was $1 \cdot 43$. This can be interpreted as a $43 \%$ increase in the duration of the works compared to the initial contract duration. On the projects managed by SKAA, then, it is possible that there was consistent underspend at the cost of delaying the delivery of goods, works, etc. This example shows the type of analysis needed across the indicators to arrive at a final view of the performance on the project(s).

Table 4 provides the range of mean value of the indicators and the proposed yardsticks for future use. The existing best performance in terms of cost growth in the contracts studied compared well with construction industry benchmarks in the United States ${ }^{18}$ — that is, an equivalent cost growth (R1) and time growth (R2) are 0.92 and 1.08 respectively. Kaka and Price $^{19}$ reported an equivalent $\mathrm{R} 2$ for their data relating to infrastructure construction in the United Kingdom to be 1.035. The cost growth of the contract in this UK study was approximately $3 \%$ cost growth, which is close to that reported

\begin{tabular}{|c|c|c|c|c|c|}
\hline Organisational context & Country & $\begin{array}{l}\text { No. of } \\
\text { non-community } \\
\text { contracts }\end{array}$ & $\begin{array}{l}\text { No. of } \\
\text { community } \\
\text { contracts }\end{array}$ & $\begin{array}{l}\text { Mean } \\
\text { contract } \\
\text { cost: } \\
\text { US\$ }\end{array}$ & $\begin{array}{l}\text { Mean } \\
\text { contract } \\
\text { duration: } \\
\text { days }\end{array}$ \\
\hline $\begin{array}{l}\text { Poverty-related projects (project management } \\
\text { unit and city level authority) (SIP) }\end{array}$ & India & 39 & 11 & 1200 & 53 \\
\hline $\begin{array}{l}\text { Colombo Municipal Corporation (drainage and } \\
\text { project division) (city authority) (CMC) }\end{array}$ & Sri Lanka & 85 & 0 & & \\
\hline $\begin{array}{l}\text { National Housing and Development Authority } \\
\text { (NHDA) }\end{array}$ & Sri Lanka & 0 & 59 & 5335 & 76 \\
\hline Clean Settlement Project Unit (CSPU) & Sri Lanka & 0 & 11 & 6108 & 83 \\
\hline $\begin{array}{l}\text { Faisalabad Development Authority/Water and } \\
\text { Sanitation Agency (city authority and project } \\
\text { management unit) (FDA) }\end{array}$ & Pakistan & 98 & 102 & 716 & 46 \\
\hline $\begin{array}{l}\text { Karachi Municipal Corporation and Karachi } \\
\text { Development Authority (city authority) } \\
\text { (KMC/KDA) }\end{array}$ & Pakistan & 130 & 56 & 75224 & 244 \\
\hline $\begin{array}{l}\text { Sindh Katchi Abadi Authority (provincial } \\
\text { authority) (SKAA) }\end{array}$ & Pakistan & 53 & 28 & 6268 & 74 \\
\hline Orangi Pilot Project (NGO) (OPP) & Pakistan & 0 & 71 & 152 & | | \\
\hline Anjuman-e Samaji-Behbood (CBO) (ASB) & Pakistan & 0 & 56 & 188 & 8 \\
\hline Total & & 405 & 394 & & \\
\hline $\begin{array}{l}\text { Note: For currency conversion } \\
\begin{aligned} E 1 \cdot 00 & =115 \text { Sri Lankan rupees } \\
& =70 \text { Indian rupees } \\
& =80 \text { Pakistani rupees } \\
& =\text { US\$1.6 }\end{aligned}\end{array}$ & & & & & \\
\hline
\end{tabular}




\begin{tabular}{|c|c|c|c|c|c|}
\hline Items & & Mean & Std dev. & Median & Range \\
\hline \multicolumn{6}{|c|}{ Group I. Sindh Katchi Abadi Authority: } \\
\hline & Cost growth & 0.67 & 0.02 & 0.67 & 0.04 \\
\hline R2 & Time growth & $1 \cdot 43$ & 0.38 & 1.44 & 0.38 \\
\hline & Lead time & 1.85 & $2 \cdot 92$ & 0.89 & $9 \cdot 63$ \\
\hline & Accuracy of preliminary technical estimates & & & & \\
\hline & Proximity of engineers' estimated cost and the initial contract cost & $1 \cdot 00$ & 0.00 & $1 \cdot 00$ & 0.00 \\
\hline & Proximity of engineers' estimated cost and the final contract cost & $1 \cdot 49$ & 0.04 & $1 \cdot 48$ & $0 \cdot 10$ \\
\hline & Time taken from approval stage to reach the tender inviting stage or equivalent stage & $57 \cdot 00$ & $80 \cdot 51$ & $24 \cdot 50$ & $209 \cdot 00$ \\
\hline TL6 & Time taken from approval stage to contract stage & $85 \cdot 00$ & $92 \cdot 53$ & $61 \cdot 50$ & $289 \cdot 00$ \\
\hline & Time taken between tender invitation and the start of contract & - & - & - & - \\
\hline TLI3 & Time taken to start operation and maintenance after the contract is completed & $16 \cdot 00$ & $9 \cdot 21$ & $15 \cdot 00$ & $29 \cdot 00$ \\
\hline \multicolumn{6}{|c|}{ Group 2. Poverty-related projects (project management unit and city-level authority) (SIP): } \\
\hline 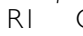 & Cost growth & 0.92 & $0 \cdot 10$ & 0.94 & 0.28 \\
\hline & Time growth & 1.66 & 0.94 & $1 \cdot 30$ & $2 \cdot 62$ \\
\hline & Lead time & 1.73 & $2 \cdot 47$ & 0.40 & 6.08 \\
\hline & Accuracy of preliminary technical estimates & $1 \cdot 00$ & 0.01 & $1 \cdot 00$ & 0.03 \\
\hline & Proximity of engineers' estimated cost and the initial contract cost & 1.05 & 0.23 & 1.08 & 0.78 \\
\hline & Proximity of engineers' estimated cost and the final contract cost & $1 \cdot 16$ & 0.33 & $1 \cdot 14$ & 1.04 \\
\hline TLI & Time taken from approval stage to reach the tender inviting stage or equivalent stage & $28 \cdot 50$ & $24 \cdot 39$ & $17 \cdot 50$ & $51 \cdot 00$ \\
\hline & Time taken from approval stage to contract stage & $92 \cdot 25$ & $144 \cdot 40$ & $21 \cdot 00$ & $364 \cdot 00$ \\
\hline TL9 & Time taken between tender invitation and the start of contract & $17 \cdot 00$ & $32 \cdot 03$ & $1 \cdot 50$ & $65 \cdot 00$ \\
\hline TLI3 & Time taken to start operation and maintenance after the contract is completed & $40 \cdot 00$ & $21 \cdot 26$ & $39 \cdot 00$ & 48.00 \\
\hline \multicolumn{6}{|c|}{ Group 3. Faisalabad Development Authority/Water and Sanitation Agency (city authority and project management unit) (FDA): } \\
\hline 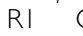 & Cost growth & 0.97 & 0.06 & 1.00 & $0 \cdot 30$ \\
\hline & Time growth & 0.77 & 0.51 & $0 \cdot 70$ & 3.85 \\
\hline & Lead time & 0.68 & 1.00 & 0.51 & $7 \cdot 20$ \\
\hline & Accuracy of preliminary technical estimates & & & & \\
\hline & Proximity of engineers' estimated cost and the initial contract cost & $1 \cdot 25$ & $1 \cdot 13$ & 1.00 & $1 \cdot 13$ \\
\hline & Proximity of engineers' estimated cost and the final contract cost & $1 \cdot 32$ & $1 \cdot 14$ & 1.02 & $6 \cdot 84$ \\
\hline & Time taken from approval stage to reach the tender inviting stage or equivalent stage & - & - & - & - \\
\hline TL6 & Time taken from approval stage to contract stage & $31 \cdot 00$ & $31 \cdot 19$ & $25 \cdot 50$ & $216 \cdot 00$ \\
\hline TL9 & Time taken between tender invitation and the start of contract & - & - & - & - \\
\hline TLI3 & Time taken to start operation and maintenance after the contract is completed & - & - & - & - \\
\hline \multicolumn{6}{|c|}{ Group 4. Orangi Pilot Project (NGO) (OPP): } \\
\hline & Cost growth & 1.08 & $0 \cdot 31$ & $1 \cdot 14$ & 0.75 \\
\hline & Time growth & $1 \cdot 59$ & 1.57 & 1.00 & $5 \cdot 83$ \\
\hline & Lead time & - & - & - & - \\
\hline & Accuracy of preliminary technical estimates & - & - & - & - \\
\hline & Proximity of engineers' estimated cost and the initial contract cost & 1.00 & 0.00 & 1.00 & 0.00 \\
\hline & Proximity of engineers' estimated cost and the final contract cost & 1.01 & 0.35 & 0.88 & 0.86 \\
\hline & Time taken from approval stage to reach the tender inviting stage or equivalent stage & - & - & - & - \\
\hline & Time taken from approval stage to contract stage & - & - & - & - \\
\hline TL9 & Time taken between tender invitation and the start of contract & - & - & - & - \\
\hline TLI3 & Time taken to start operation and maintenance after the contract is completed & - & - & - & - \\
\hline \multicolumn{6}{|c|}{ Group 5. National Housing and Development Authority (NHDA): } \\
\hline RI & Cost growth & $1 \cdot 15$ & 1.59 & 0.92 & $10 \cdot 56$ \\
\hline & Time growth & $2 \cdot 10$ & 1.39 & 1.63 & $6 \cdot 55$ \\
\hline & Lead time & 0.64 & 0.59 & 0.44 & $2 \cdot 33$ \\
\hline & Accuracy of preliminary technical estimates & 1.03 & 0.02 & 1.02 & 0.08 \\
\hline & Proximity of engineers' estimated cost and the initial contract cost & 1.00 & 0.00 & 1.00 & 0.00 \\
\hline & Proximity of engineers' estimated cost and the final contract cost & 1.09 & 0.13 & 1.09 & 0.50 \\
\hline & Time taken from approval stage to reach the tender inviting stage or equivalent stage & 39.72 & $64 \cdot 38$ & 18.00 & $256 \cdot 00$ \\
\hline & Time taken from approval stage to contract stage & $47 \cdot 06$ & $54 \cdot 16$ & $32 \cdot 00$ & $210 \cdot 00$ \\
\hline TL9 & Time taken between tender invitation and the start of contract & $24 \cdot 67$ & $47 \cdot 64$ & $5 \cdot 50$ & $181 \cdot 00$ \\
\hline TLI3 & Time taken to start operation and maintenance after the contract is completed & $56 \cdot 78$ & $85 \cdot 43$ & $16 \cdot 00$ & $285 \cdot 00$ \\
\hline \multicolumn{6}{|c|}{ Group 6. Clean Settlement Project Unit (CSPU): } \\
\hline & Cost growth & 0.86 & 0.11 & 0.88 & 0.35 \\
\hline & Time growth & $|\cdot 3|$ & 0.71 & 1.00 & $2 \cdot 50$ \\
\hline & Lead time & 1.79 & 1.78 & $1 \cdot 13$ & $4 \cdot 98$ \\
\hline & Accuracy of preliminary technical estimates & $1 \cdot 10$ & 0.17 & 1.03 & 0.55 \\
\hline & Proximity of engineers' estimated cost and the initial contract cost & 1.02 & 0.06 & 1.00 & 0.22 \\
\hline & Proximity of engineers' estimated cost and the final contract cost & $1 \cdot 20$ & $0 \cdot 19$ & $1 \cdot 14$ & 0.53 \\
\hline & Time taken from approval stage to reach the tender inviting stage or equivalent stage & 74.73 & $81 \cdot 72$ & 38.00 & $289 \cdot 00$ \\
\hline & Time taken from approval stage to contract stage & 96.91 & 67.89 & $81 \cdot 00$ & $214 \cdot 00$ \\
\hline TL9 & Time taken between tender invitation and the start of contract & - & - & - & - \\
\hline TLI3 & Time taken to start operation and maintenance after the contract is completed & 115.09 & $86 \cdot 43$ & 114.00 & $263 \cdot 00$ \\
\hline
\end{tabular}




\begin{tabular}{|c|c|c|c|}
\hline Performance indicators & $\begin{array}{l}\text { Range of } \\
\text { mean values }\end{array}$ & Midpoints & $\begin{array}{l}\text { Proposed } \\
\text { yardsticks }\end{array}$ \\
\hline Cost growth (RI) & $0 \cdot 67-1 \cdot 15$ & 0.91 & $\pm 9 \%$ \\
\hline Time growth (R2) & $0 \cdot 77-2 \cdot 10$ & $1 \cdot 43$ & $\pm 20 \%$ \\
\hline Lead time $(\mathrm{R} 3)$ & $0.64-1.85$ & $1 \cdot 24$ & $\pm 20 \%$ \\
\hline Accuracy of preliminary technical estimates (R4) & $1 \cdot 00-1 \cdot 10$ & 1.05 & $\pm 5 \%$ \\
\hline Proximity of engineers' estimated cost and the initial contract cost (R5) & $\mid \cdot 00-1 \cdot 25$ & $1 \cdot 12$ & $\pm 12 \%$ \\
\hline Proximity of engineers' estimated cost and the final contract cost (R6) & $\mid \cdot 01-1 \cdot 49$ & $\mid \cdot 25$ & $\pm 25 \%$ \\
\hline Time taken from approval stage to reach the tender inviting stage or equivalent stage (TLI) & $28 \cdot 50-74 \cdot 73$ & $51 \cdot 46$ & 50 days \\
\hline Time taken from approval stage to contract stage (TL6) & - & - & - \\
\hline Time taken between tender invitation and the start of contract (TL9) & $17 \cdot 00-24 \cdot 67$ & $20 \cdot 83$ & 20 days \\
\hline Time taken to start operation and maintenance after the contract is completed (TLI3) & $16.00-115.09$ & $65 \cdot 54$ & 65 days \\
\hline
\end{tabular}

Table 4. Summary of inter-group performance analysis and proposed yardsticks

for the USA. The following are some salient points on the general performance of community contracts.

The performance with respect to cost growth was superior to that of time growth, since there seemed to be more effective control of cost than control of time in the contracts.

Cost growth performance was superior in groups from SKAA and FDA (Faisalabad Development Authority). This factor indicates that the capacity to control relatively small-scale contracts is available in those organisations, in part due to the fact that cost escalation of more than 10\% requires approval of higher officials. In contrast, the time growth, generally, was relatively high. This was because the officials did not attach much priority to time control, with contract time extensions being granted routinely. The other explanations given for the poor time performance were civil riots, monsoon rains, unavailability of materials and unstable political situations.

R4 (accuracy of preliminary technical estimated) gives an indication of the accuracy of the estimates for sanction costs. The best performance was in slum improvement projects (SIP) (poverty-related projects in India), which was right on target. The variation of R1 (cost growth) about the contract price was calculated: as the contract cost increases, so does the cost growth. The variation of R2 (time growth) about the contract indicates that the time growth increases with the contact size.

There is scope for improvements in the engineers' estimates R5 (proximity of engineers' estimated cost and the initial contract cost) and R6 (proximity of engineers' estimated cost and the final contract cost) with regard to initial and final contract costs. This may well be related to the fact that the works procedures dictate the use of national government rates for estimation purposes, which in many cases were out of date and bore no relation to market rates.

On average, the best lead/preparation time (R3) is $68 \%$ of the construction contract duration. In terms of the contract time, the lead time can be as high as 179\%, as can be seen in the case of the Clean Settlement Project Unit, Sri Lanka (CSPU). The time taken for the preparation of the contract requires further examination. No data on lead (preparation) time indicators exist from countries other than those in this study. Lead times of almost 50\% of the contract duration are very high considering the standard conditions for public works. There is a need to streamline the procedure for awarding small-scale contracts to reduce these high lead times, and so improve on the delivery of urban services. The chain of administrative approval may be reduced by delegation of authority. There is also a need for officials to monitor their pre-contract performance; the indicators developed here could be used for that purpose.

Table 5 shows the performance indicators with respect to community labour days and training for the different project groups. These indicators allow an estimate of the financial benefit to the community and the circulation of money in the local economy. Separate factors are used for male and female workers; for example, based on the study of a project the following data are obtained.

- 300 unskilled labour days @ \$2 per day=\$600.

- 40 skilled labour days @ \$5 per day=\$200.

- Materials purchased locally @ 40\% of contract sum (say $\$ 5000)=\$ 2000$.

This results in an additional $\$ 2800$ circulating within the local economy.

Table 6 indicates that members of the community-especially women-were trained in various aspects of provision of infrastructure. This is basically an added value of communitypartnered procurement. Training enables participants to monitor the quality of work in micro-projects and improves the capacity of the local community to manage its urban services, which in turn makes those services more sustainable. The research revealed that of all the projects reviewed there were no recorded instances of work being rejected on the grounds of poor quality; in fact, community members reported high levels of satisfaction with community-partnered procurement because the 'social embeddedness' of contractors in the local community creates a social pressure to do a good job. Residents also stated that community-partnered contracting meant that if a problem developed with the facility they could report it to the contractor, which created a local accountability for the work. Furthermore, any wrongdoing on the part of the contractor that causes harm to the local community could lead to social ostracism. However, anecdotal evidence suggests that work done by micro-contracts is by no means free of faults; these either go undetected, unreported or have no action taken about them. This latter point implies collusion between the supervising authority and the contractor. 


\begin{tabular}{|c|c|c|c|c|c|}
\hline Contexts & Maximum & Minimum & Range & Mean & Mode \\
\hline SKAA male unskilled & 575 & 20 & 555 & $202 \cdot 00$ & 20 \\
\hline SKAA male skilled & 70 & 42 & 28 & $56 \cdot 00$ & 42 \\
\hline NHDA male unskilled & 40 & 15 & 25 & $26 \cdot 11$ & 30 \\
\hline NHDA female unskilled & 45 & 20 & 25 & $35 \cdot 28$ & 40 \\
\hline NHDA male skilled & 25 & 10 & 15 & $20 \cdot 28$ & 20 \\
\hline NHDA female unskilled & 50 & 20 & 30 & $29 \cdot 17$ & 30 \\
\hline SIP male unskilled & 500 & 115 & 385 & $299 \cdot 75$ & 115 \\
\hline SIP female unskilled & 300 & 85 & 215 & $165 \cdot 75$ & 85 \\
\hline SIP male skilled & 100 & 4 & 96 & $47 \cdot 25$ & 4 \\
\hline SIP female skilled & 0 & 0 & 0 & 0.00 & 0 \\
\hline CSPU male unskilled & 50 & 10 & 40 & $24 \cdot 55$ & 20 \\
\hline CSPU female unskilled & 75 & 15 & 60 & $35 \cdot 91$ & 30 \\
\hline CSPU male skilled & 30 & 10 & 20 & $18 \cdot 18$ & 20 \\
\hline CSPU female skilled & 50 & 10 & 40 & $28 \cdot 18$ & 20 \\
\hline
\end{tabular}

SIP = Poverty-related projects (project management unit and city level authority; CSPU = Clean Settlement Project Unit; NHDA = National Housing and Development Authority; SKKA = Sindh Katchi Abadi Authority.

Table 5. Community labour days per contract

\begin{tabular}{|c|c|c|c|c|c|}
\hline Contexts & Maximum & Minimum & Range & Mean & Mode \\
\hline SIP number of days training: formal & 2 & 0 & 2 & $0 \cdot 25$ & 0 \\
\hline SIP number of days training: informal & 15 & 0 & 15 & $6 \cdot 00$ & 5 \\
\hline SIP number of women trained & 5 & 2 & 3 & $3 \cdot 50$ & 2 \\
\hline NHDA number of days training: formal & I & 0 & । & 0.89 & । \\
\hline Number of days training: informal & 2 & 0 & 2 & 1.00 & 2 \\
\hline Number of women trained & 80 & 0 & 80 & $42 \cdot 17$ & 30 \\
\hline CSPU number of days training: formal & 3 & । & 2 & $1 \cdot 73$ & 2 \\
\hline CSPU number of days training: informal & 8 & I & 7 & $3 \cdot 00$ & I \\
\hline CSPU number of women trained & 69 & 20 & 49 & $40 \cdot 73$ & 20 \\
\hline
\end{tabular}

See Table 5 for explanation of abbreviations.

Table 6. Number of community training days and women trained per contract

The large range of labour/training days shown in Tables 5 and 6 partially reflects the amount of skilled and unskilled labour required from community members for construction and operations and maintenance of services within the case study settlements. However, this discrepancy also reflects the varying levels of community engagement in community-partnered contracts; for example, the number of women trained was much higher in National Housing and Development Authority (NHDA) schemes in Sri Lanka than SIP schemes in India. This difference reflects a number of policy initiatives in Sri Lanka over recent years that have promoted the concept of self-help and active beneficiary participation in planning and construction of common amenities in low-income settlements.

Wider impacts of community contracting include the following.

(a) Social and cultural impacts: changed attitudes and social interaction for the better; cooperation between community members; provision of a park enabled women and children to spend more leisure time outside the home; the park also created local social esteem, creation of local pride and confidence and a can-do attitude.

(b) Community organisational impact: built organisational capacity; feelings of empowerment; increased interaction between women; involvement in monitoring quality; increased level of ownership and care for facilities; enthusiasm for working together collectively; people more willing to pay for services.

(c) Political impacts: people more politically aware and thought more carefully about how to vote; people wanted firm commitments from politicians; increased political activism.

Most of the indicators presented in this research are concerned with performance at the level of the individual contract. However, it is important to recognise that, when brought together and analysed, the information obtained through such indicators can be important in shaping programmes and policies. For instance, indicators of the local employment resulting from specific schemes featuring community-contracted procurement might provide a strong rationale for the development of changes in policy to encourage wider use of community-partnered procurement.

\section{CONCLUSIONS}

This research has presented a method of performance analysis using indicators for the appraisal, monitoring and evaluation of micro-projects that are procured by community-contracting 
schemes. The findings comprise indicators and key yardsticks developed by research involving not only professional experts but also other stakeholders including the community and endusers. In addition to standard measures of time and cost, the performance indicators also refer to some of the wider socioeconomic impacts of community contracting for urban services. These wider socio-economic impacts arising from communitypartnered micro-projects can lead to more sustainable infrastructure through meeting local stakeholders' needs, community empowerment and capacity building.

Performance indicators were developed to assess time, cost, quality of work and socio-economic issues. In general, it was found that costs for community-contracted micro-projects were normally very close to being on target. The quality of infrastructure and service provision also tended to be superior to that envisioned. However, project duration generally exceeded the target but was still comparable to conventional contracts.

The performance analysis from this research confirms that the procurement and execution of community-partnered smallscale contracts is not only a technical matter but also has wider socio-economic impacts. The overall performance of the community-partnered micro-projects was found to be comparable to or better than the conventional micro-contracts; in addition, the performance of these projects in terms of socio-economic elements was likely to far exceed that of conventional microprojects. For example, the number of community labour days generated by micro-contracts injects significant money into the local economy.

The list of indicators and yardsticks represents a set of metrics from which procurement teams and managers can select the appropriate basis to monitor each contract under consideration. Not all the indicators need to be used on every project. Conversely, on some projects users may decide to use additional indicators to meet specific project needs.

It is concluded that through the judicious use of performance analysis and taking appropriate actions, procurement of microprojects can be improved. The findings presented, therefore, make an important contribution to the management of community-partnered micro-projects in developing countries.

\section{ACKNOWLEDGEMENTS}

The Department for International Development (DFID), United Kingdom, supported this research, and for that the authors are very grateful. The views expressed are not necessarily those of DFID. Special thanks are due to the contributors from South Asia, without whom progress could not have been made.

\section{REFERENCES}

1. United Nations Centre for Human Settlements. Cities in a Globalizing World: Global Report on Human Settlements. EarthScan Publications, London, 2001.
2. United Nations Centre for Human Settlements. Global Report on Human Settlements. United Nations Centre For Human Settlements, Nairobi, 1987.

3. United Nations Centre for Human SetTlements. An Urbanising World: Global Report on Human Settlements, 1996. Oxford University Press, Oxford, 1996.

4. PARKIN S. Sustainable development: the concept and the practical challenge. Proceedings of the Institution of Civil Engineers, Civil Engineering, 2000, 138, No. 5, 3-8.

5. PARKIN S. Contexts and drivers for operationalising sustainable development. Proceedings of the Institution of Civil Engineers, Civil Engineering, 2000, 138, No. 5, 9-15.

6. WoRLD BANK. Entering the 21st Century: World Development Report 1999/2000. Oxford University Press, Oxford, 2000.

7. SoHAIL M. and BALDWIN A. N. Performance indicators for 'micro-projects' in developing countries. Construction Management and Economics, 2004, 22, 11-23.

8. Pathirana V. and Sheng Y. K. The community contract system in Sri Lanka: an innovative approach for the delivery of basic services to the urban poor. Habitat International, 1992, 16, No. 4, 3-14.

9. Sohail M., Miles D. W. J. and Cotton A. P. Developing monitoring indicators for urban micro contracts in South Asia. International Journal of Project Management, 2002, 20, 583-591.

10. SoHAIL M. An Investigation into the Procurement of Urban Infrastructure in Developing Countries. PhD thesis, Loughborough University, 1997.

11. SoHAIL M. and BaLdWIN A. N. Partnering with communityan option for infrastructure procurement. Proceedings of the Institution of Civil Engineers, Municipal Engineer, 2001, 145, No. 4, 293-297.

12. SoHAIL M. and CotTon A. Performance Monitoring of Microcontracts for the Procurement of Urban Infrastructure. WEDC, Loughborough University, 2000.

13. ANDERSON B. and PetTerSEN P. The Benchmarking Handbook. Chapman and Hall, London, 1996.

14. Latham M. Constructing the Team: Joint Review of Procurement and Contractual Arrangements in the United Kingdom Construction Industry. Final Report, HMSO, London, 1994.

15. Egan J. L. Rethinking Construction: The Report of the Construction Task Force. DETR, London, 2000.

16. Department of the EnVIRONMENT, TRANSPORT AND tHe Regions. KPI Report for the Minister for Construction by the KPI Working Group UK. DETR, London, 2000.

17. Construction Best Practice Programme (CBPP). Available on the internet at: www.cbpp.org.uk

18. Fisher D., Meistschin S. and Pollock Jr. D. R. Benchmarking in the construction industry. Journal of Management In Engineering, ASCE, 1995, 11, No. 1, 50-57.

19. KaKa A. and Price A. D. F. Relationship between value and duration of construction projects. Construction Management and Economics, 1991, 9, No. 4, 383-400.

Please email, fax or post your discussion contributions to the secretary by I June 2005: email: journals@ice.org.uk; fax: +44 (0)20 7665 2294; or post to Journals Department, Institution of Civil Engineers, I-7 Great George Street, London SWIP 3AA. 